Int. J. Dev. Biol. 58: 727-732 (2014)

doi: $10.1387 / \mathrm{ijdb} .150026 \mathrm{dd}$

\title{
Snakes: hatching of a model system for Evo-Devo?
}

\author{
ISABEL GUERREIRO ${ }^{1}$ and DENIS DUBOULE ${ }^{*, 1,2}$ \\ ${ }^{1}$ Department of Genetics and Evolution, University of Geneva and \\ ${ }^{2} S c h o o l$ of Life Sciences, Federal Institute of Technology, Lausanne, Switzerland
}

\begin{abstract}
Evo-Devo studies rely on a collection of animal model systems belonging to different phylogenetic branches to try and understand how organisms carrying a similar set of genes and pathways can develop into such a variety of shapes and sizes. The squamate clade, however, has only recently started to receive the attention it deserves in particular due to extreme morphological and metabolic aspects and, consequently, the important insights that it could bring in different fields. The recent sequencing of several squamate genomes as well as the generation of high quality trancriptomes for different snake tissues now provide the necessary tools to complement biological studies. Here, we briefly report on recent work involving developing snake embryos to illustrate their interest to assess vertebrate developmental mechanisms. We also discuss the relevance to use snake species as Evo-Devo model systems and potential ways to cross the important limitations intrinsically associated with developmental and genetic studies of these fascinating animals.
\end{abstract}

KEY WORDS: Hox gene, snake, model organism, axial extension, vertebrae

Look like th' innocent flower, but be the serpent under 't

Lady Mcbeth

Snakes have always had a special position within the animal kingdom, as judged by the enormous number and diversity of associated symbols, in religious, mythological or historical contexts. The fact that these animals carry dual positive and negative representations - the good and the evil - echoes their morphological ambiguity as vertebrates crawling like worms. This particular phenotype, however, is only one of the many extreme forms found within vertebrates, a taxon that displays a large variety of organisms, while sharing almost the same set of developmental genes and pathways.

Ever since the mid 1980's, when molecular genetics started to revive the links between the fields of evolution and developmental biology, a shift in paradigm occurred whereby species-specific genes were no longer considered as the source of diversity, leading to the necessity to explain how comparable genetic materials can generate distinct organisms (discussed e.g. in (Carroll, 2005, De Robertis, 2008). With the advent of large-scale comparative genomic analyses, some solutions to this conundrum start to emerge. For example, a high conservation of coding genes seems to be counterbalanced by important variations in their regulatory modalities, as exemplified by recent global comparisons between the mouse and the human regulomes (Cheng et al., 2014, Stergachis et al., 2014, Yue et al., 2014). However, a more comprehensive view of this question requires the experimental integration of as many species as possible, in particular from phylogenetically distant groups such that predictions formulated when studying particular cases can be readily challenged, corrected and enriched by considering potential variations thereof.

\section{'Snakes' as model organisms?}

In this context, various views have been proposed regarding the choice of strategies to best use the variety of animal species to understand their intimate molecular and mechanistic commonalities (see e.g. (Duboule, 2010, Milinkovitch and Tzika, 2007). One extreme (reductionist) view is that the full understanding of a single organism, within a given taxon, will unravel all basic mechanisms at work and thus naturally explain all of their variants. Accordingly, efforts should all concentrate on the same model system. The opposite (holistic) view states that only the study of all species on earth will provide us with a satisfactory level of understanding since each of them will bring an essential contribution due to its

Abbreviations used in this paper: AER, apical ectodermal ridge; dpo, days post oviposition; PSM, presomitic mesoderm; SMGT, sperm-mediated gene transfer.

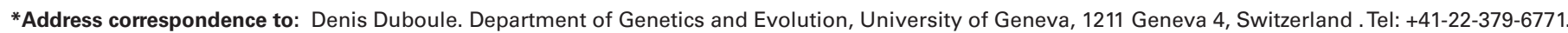
Fax: +41-22-379-6795. E-mail: Denis.Duboule@unige.ch ; Denis.Duboule@epfl.ch
}

Accepted: 20 December 2014.

ISSN: Online 1696-3547, Print 0214-6282

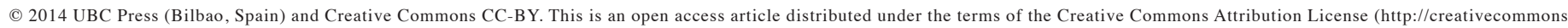

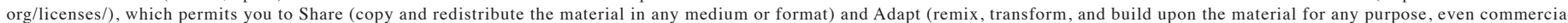

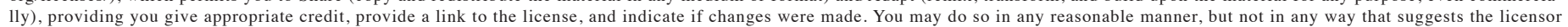
endorses you or your use. Printed in Spain 
evolutionary success. The evo-devo community currently implements a more reasonable and pragmatic strategy, whereby selected species are studied, if possible representative of all major groups such that results can be shared, compared and integrated into a general conceptual framework. The criteria to select such epistemic objects are however not trivial to define (see (Tzika and Milinkovitch, 2008) and often reflect a utilitarian view of the problem, as illustrated by qualifying species-specific traits as displaying experimental 'advantages' or 'disadvantages', which usually qualifies the capacity of an animal to deliver the expected results.

Within vertebrate amniotes, while mammals are well represented as model systems, the huge and diverse group of sauropsids is clearly underrepresented in laboratories, besides some bird species. Several rather limited taxons such as chelonians and crocodilians have received some attention recently, for very specific purposes (Green et al., 2014, Milinkovitch et al., 2013, Nagashima et al., 2009, Shaffer et al., 2013, Wang et al., 2013), yet the importance of Squamata is certainly not reflected in the number of species used efficiently at the bench, despite the recent releases of genome sequences for the green anole lizard (Alfoldi et al., 2011), the Burmese python (Castoe et al., 2013) the king cobra (Vonk et al., 2013) or other snakes (Gilbert et al., 2014), as well as several high quality transcriptomes (see e.g. (Schwartz et al., 2010, Tzika et al., 2011). Since a long time, however, lizards and snakes have been used to address successfully a number of specific questions, for example related to ecological research (Shine and Bonnet, 2000), to the emergence of viviparity (Murphy and Thompson, 2011) or to understand parthenogenesis (Lutes et al., 2010).

More recently, next generation sequencing has allowed to reexamine two research fields where snakes are starring for many years, i.e. the evolution of the venom system (Fry et al., 2006, Menez et al., 2006) and its potential use in drug discovery (Harvey, 2014), as well as the extraordinary metabolic adaptations of some species in response to adverse environmental conditions. Many species of snakes produce venom that is released upon biting a prey. While this liquid is best known for its dangerous properties, it also contains peptides of great biomedical potential such as for example painkillers, anesthetics or regulators of blood pressure. Recently, the genome of the king cobra was released and the transcriptome from the venom glands established, showing that toxin genes were co-opted by various mechanisms and that these genes massively expanded through gene duplications, leading to venom protein neo-functionalization (Vonk et al., 2013). This work not only provided insights into venom toxin evolution but also represents a powerful resource for identifying peptides of potential pharmacological interest.

Along with the king cobra genome, the Burmese python genome was also released and brought some important information regarding the remarkable adaptations that this snake species has experienced in its metabolism (Castoe et al., 2013). Indeed, the python has evolved a mechanism to cope with extreme feeding conditions, intercalating long periods of fasting with the ingestion of very large meals. One to three days after a large food intake, the python's small intestine, stomach, liver, pancreas, heart, lungs and kidneys undergo a 0.5 to two-fold increase in their size. However, once digestion is completed, these organs shrink back to their original dimensions. Genome sequencing together with transcriptome analysis of four organs before and after feeding, showed that rapid and massive transcriptional responses occur in multiple organ systems, which can coordinate changes in organ size and function. Interestingly, the homologs of these genes in humans are associated with metabolism, development, pathology and chromatin remodeling (Castoe et al., 2013).

These sequencing efforts have recently triggered some coordination amongst various laboratories investigating such aspects of snake biology, to try and federate forces in snake research (Castoe et al., 2012). In addition, the past few years have also seen a handful of papers starting to use snakes as a model system in a modern evo-devo context, i.e. using molecular and/or genomic tools to look at snake embryos with the aim of integrating the data within vertebrates at large. By 'snake embryos', we mean embryos derived from various species of snakes, sometimes displaying high evolutionary distances. Indeed it isn't yet clear whether one particular species will be favored as a paradigm in the future, or if the different scientific interests at stake will lead to the study of as many distinct species. Below, we briefly mention these studies and propose some considerations regarding the actual and future status of snakes as model systems in developmental biology.

\section{Manipulating snake embryos}

Like their body shape, the development of snake embryos is fascinating in many respects (Fig. 1). Snakes likely arose from ancestral lizards that adopted a burrowing lifestyle and became
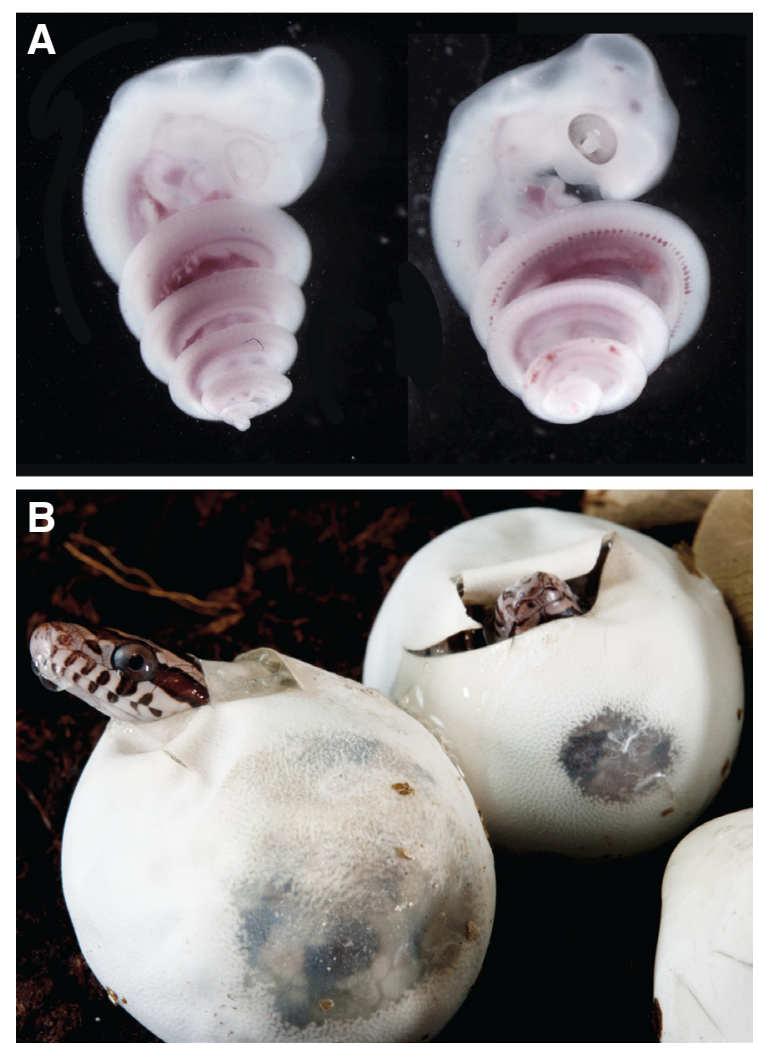

Fig. 1. Snakes as model system for developmental studies. (A) Corn snake embryos dissected at two different developmental stages: 4.5 days post oviposition (dpo) and $6.5 \mathrm{dpo}$, showing their elongated body plan. (B) Two corn snakes ecloding from their eggs (copyright Michel M. Milinkovitch, University of Geneva). Due to their oviparous or ovoviviparous strategies, snake embryos up to rather late developmental stages are difficult to obtain and a fortiori, to manipulate. 
adapted accordingly by changing their morphological and physiological characteristics, leading to elongated and limbless vertebrates (Vidal and Hedges, 2004). Such species must have undergone remarkable selective pressure to modify critical developmental mechanisms in this respect, and hence these animals should present excellent opportunities to better understand how developmental processes and pathways can be changed to generate a large variety of shapes.

The burrowing lifestyle of snake ancestors was accompanied by a considerable reduction of limbs, up to their complete disappearance. The understanding of the process underlying the loss of appendages would certainly bring critical insights into the early steps of limb field determination, budding and development. Also, it may give us a hint as to why this phenomenon arose repeatedly throughout evolution. Some snakes, however, display limb remnants, traces of their tetrapod ancestors. This is the case of pythons, a large and almost tailless snake that preys by constriction, which most likely maintained vestigial hindlimbs as pelvic spurs to assist during copulation (Held I, 2014). Such intermediate forms are key to understand the transition towards a limbless animal. Interestingly, snake limb buds were shown to differ from tetrapod buds by lacking an apical ectodermal ridge (AER) (Cohn and Tickle, 1999), the signaling center that normally controls the proximal to distal growth of limb buds (see (Tabin and Wolpert, 2007). However, the reason why an AER fails to further develop in snakes is still unknown.

Snakes have a very elongated body plan with multiple segments, displaying similar morphologies. The study of this extreme vertebrate formula may thus shed light on the nature of those mechanisms regulating the extension, segmentation and patterning of the major body axis. By looking at components of the segmentation clock (Pourquie, 2003) in developing corn snake embryos, a step was taken towards understanding the mechanism behind the large number of snake vertebrae. Gomez et al., (Gomez et al., 2008) indeed reported that, while somites were generated in snakes by using the same mechanism than in any other vertebrates, a large number of relatively small somitic condensations were produced, due to both a slower shrinkage of the mass of presomitic mesoderm (PSM) and a segmentation clock that progresses four times faster than in the mouse (Gomez and Pourquie, 2009).

\section{Hoxgenes in the evolution of the serpentiform body plan}

Changes in the expression specificity and/or function of Hox genes, a family of transcription factors involved in the patterning of the body plan in all animals, have been proposed as potential causes in the evolution of a serpentiform morphology (see refs in (Woltering, 2012). It was reported that snakes have the same set of Hox genes as any other amniote, with the notable exception of Hoxd12, which is absent from all snakes sequenced thus far. In contrast, a Hoxc3 gene is found in all Squamata, which in turn is not present in mammals (Di-Poï et al., 2010, Vonk et al., 2013). However, it is unlikely that this small change in Hox gene content would have contributed to the generation of the snake-like body plan. The absence of Hoxd12, a gene mostly involved in tetrapod limb development, may rather reflect a consequence of limblessness in snakes (e.g. (Kmita et al., 2002). Instead, either modifications in the ability of Hox proteins to properly regulate downstream target genes, or changes in the transcriptional regulation of Hox genes themselves may have accompanied the evolutionary transition towards these extreme morphologies.

In the mouse, the role of Hox genes in rib cage development has been extensively studied and Hox paralogous groups 5 to 9 were shown to organize the thoracic skeleton in a collinear manner (Mclntyre et al., 2007). Mutations within each of these genes generated somewhat overlapping mutant phenotypes, with abnormal phenotypes affecting progressively more posterior parts of the thoracic vertebrae. Therefore, different combinations of $H o x$ genes are necessary to generate morphologically distinct vertebral identities (Mclntyre et al., 2007). The first detailed analysis of Hox gene expression specificities in the corn snake revealed that the observed segmental uniformity did not reflect a homogenization of Hox gene expression domains. Somehow unexpectedly, these expression domains were also found to be organized in a collinear manner along the anterior to posterior axis, as in the mouse (Fig. 2) (Woltering et al., 2009). However, recent analyses of snake vertebrae morphology (Head and Polly, 2015) have shown that snakes have four different types of pre-cloacal vertebrae (like other vertebrates) and hence the de-regionalization of the primaxial skeleton (including dorsal ribs) may not be as pronounced as previously thought. In contrast, an important transformation comes from the loss of the abaxial rib cage (the ventral part, including the sternum).

Both Hoxc10 and Hoxa10, which in mammals encode proteins with a strong rib-repressing activity (Wellik, 2003), were nevertheless unexpectedly found transcribed in somites of early corn snake embryos, at body levels corresponding to rib-bearing vertebrae (Di-Poï et al., 2010, Woltering et al., 2009), suggesting that such proteins were no longer able to repress rib formation. Further work showed that the snake Hoxa10 protein was nevertheless able to repress rib formation when overexpressed in the mouse presomitic mesoderm, suggesting that the snake Hoxa10 protein can still exert this particular rib-suppressing property. One potential explanation to this conundrum was provided by the presence of a single polymorphism in the Hox binding site of a target gene enhancer element, making the latter unresponsive to the presence of Hox10 transcription factors. In this case, therefore, a mutation in a binding site rather than a protein loss of function caused the persistence of ribs at places where they had disappeared in other amniotes (Guerreiro et al., 2013).

Ectopic activation of Hox genes produces homeotic transformations, where a part of the body takes the identity of another one (ref. in (Duboule and Morata, 1994). Likewise, changing Hox gene expression in time and space in the course of evolution, via regulatory modifications may have induced significant morphological changes. As other developmental loci implementing complex regulations (Simons et al., 2006), amniote Hox clusters tend to be poor in repeated elements, a situation perhaps selected to prevent interferences with long-range regulations by global enhancers (see (Duboule, 2007). In this context, the fact that all squamates display rather high amounts of transposable elements within Hox clusters, which are also substantially larger than their amniote counterparts (Di-Poï et al., 2009, Di-Poï et al., 2010), suggests that such elements may have had some consequence upon Hox gene regulation. For example, the corn snake Hoxd13 and Hoxa13 genes have significantly low levels of expression during tail bud development (Di-Poï et al., 2010), the place where somites are added during body extension. Because these genes are involved in regulating axial extension (Young et al., 2009), see (Young and 
Deschamps, 2009), their altered regulation, in conjunction with a rapid segmentation clock (Gomez et al., 2008), could account for (part of) the elongated snake body plan (Di-Poi et al., 2010, Woltering, 2012).

\section{Still a long way to go}

While these different results suggest some avenues to investigate the drastic modification that occurred in the snake body plan, they nevertheless remain at a rather descriptive or theoretical level. As in many such cases of emerging evo-devo model organisms, hypotheses can be proposed but their experimental verifications can hardly be carried out. For instance, slowing down the segmentation clock while keeping the same developmental pace should in principle give less somites yet of a larger size. Likewise, strongly activating Hox group 13 genes in the early tail bud should lead to a snake of a shorter body length. The same holds true for the genomic tools and their application based on snake genome sequences, such as ChIP-seq, DNA methylation analyses or chromatin structure experiments. While they may reveal essential variations between snakes and other amniotes, the functional significance of such variations will be difficult to ascertain.

Unfortunately, none of these experiments can be carried out in snakes thus far, mostly due to the biology of these animals, their oviparous or ovoviviparous reproductive strategies and the time needed to reach sexual maturation. An alternative approach
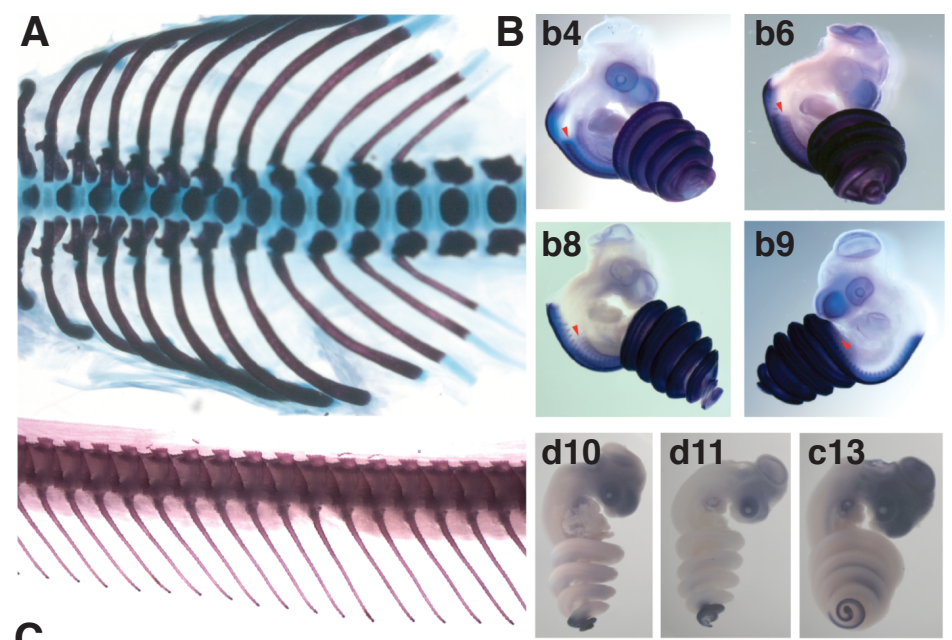

C

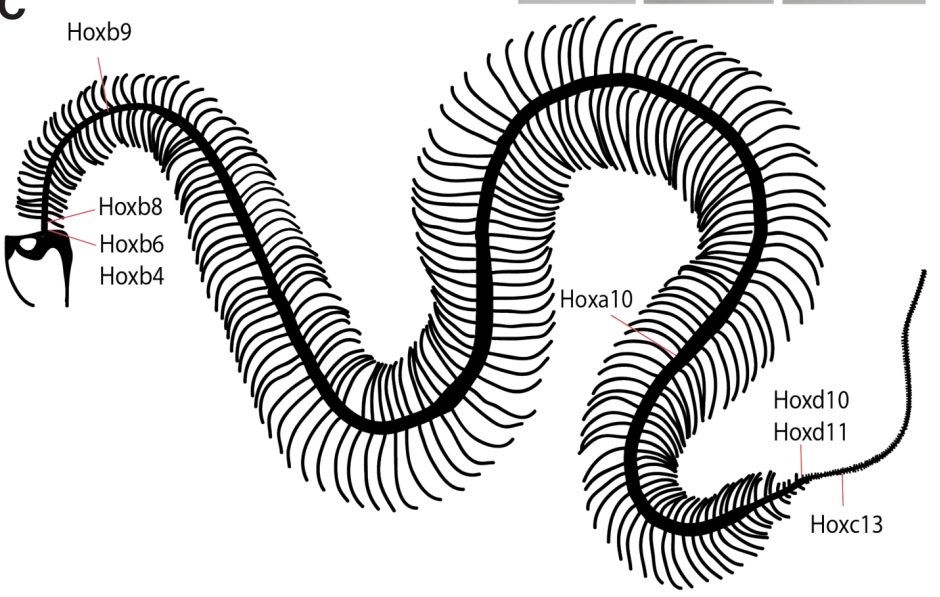

is to use a system amenable to functional studies such as mice, where snake elements (genes, enhancers, binding sites) can be introduced and analyzed. For example, assuming that a mutation rendered a snake Hox protein unable to properly interact with target genes, this protein as well as its 'corrected' version could be assayed in a transgenic mouse context to see if a similar effect is scored. Likewise, a mutation within a snake enhancer sequence, which would make a target gene unresponsive to a Hox protein could be introduced within the cognate mouse sequence. Also, to address cases where differential Hox gene regulation is observed between snakes and mice, large pieces of the snake genome could be introduced into mice such as to see if the variability is encoded into the transposed piece or by upstream regulators. In all these cases, however, the results will mostly tell us about how the mouse can accommodate snake material, rather than truly demonstrating a causative effect of the transgenic material upon the extreme snake morphologies. To answer the latter question, hypotheses must be functionally checked in the appropriate context: the snakes themselves.

This point raises again the general nature of model systems in biological studies and the necessity to develop the appropriate tools in a large variety of representative animal species. In this context, some important obstacles must still be removed before snakes become a fully useful model system in developmental biology. A species would be required that can reproduce all year long, lay many eggs at a not-too-late developmental stage with, if possible, some

level of inbreeding. Yet the most difficult obstacle to overcome will be to make snakes genetically modifiable. For the moment, it is difficult to imagine how this could be achieved efficiently and sperm-mediated gene transfer (SMGT; see (Smith and Spadafora, 2005) may be the most promising approach to develop. This approach, however, has not proven particularly successful in other animal species thus far.

The relationship between evo-devo research and the realm of animal model systems is complex and reflects the variety of mindsets making this large community of scientists. Often, a species is selected due to one particular trait, which may help understand a question of wide interest due to the accumulation of knowledge derived from other well-established systems such as e.g. digit reduction in tetrapods (Cooper et al.,

Fig. 2. Hox gene expression and its relationship to the snake axial skeleton. (A) Dorsal view of a mouse rib cage (top), compared to a snake rib cage (lateral view, bottom). Unlike the snake (but see (Head and Polly, 2015), the mouse rib cage displays a variety of rib morphologies, as established by the succession of Hox gene expression domains (e.g. (Kessel and Gruss, 1991). (B) Hox gene expression territories during the development of the extended body axis in the corn snake. A collinear distribution is observed in the snake, despite the lack of a clear segmental regionalization. For example, in situ hybridization of 2.5 to 3.5dpo corn snake embryos with Hoxb4, Hoxb6, Hoxb8, Hoxb9, Hoxd10, Hoxd11 and Hoxc13-specific probes show that the anterior boundary of gene expression shifts successively towards more posterior regions of the embryo, in a collinear manner (data from (Di-Poï et al., 2010, Woltering et al., 2009). Anterior limits of gene expression for Hoxb4 to Hoxb9 are indicated with a red arrowhead. (C) Schematic representation of an adult snake skeleton, with the approximate positions of anterior limits of mesodermal Hox gene expression, as transposed from expression studies in embryos. Selected Hox gene expression anterior boundaries are indicated (Woltering et al., 2009). 
2014). Likewise, a deep mechanistic understanding, at the cellular level, of one precise developmental situation can be successfully complemented by the analysis of as many variants as possible within closely related species (Arnoult et al., 2013, Sommer, 2009). Alternatively, new species can be developed as genuine model systems, by complementing a fair knowledge of the biology of the animal by modern genomic tools and a potential for genetic analyses (Satoh and Levine, 2005). It is however necessary that reliable functional approaches be developed and adapted to each model and to critically assess their efficiency and relevance (see (Kok et al., 2014). At the other end of the spectrum, PCR products can be amplified from any animal species and gene expression recorded and compared, leading to more or less significant inferences (Duboule, 2005).

After all, the heuristic value of a given animal model is hardly predictable and can only be judged retrospectively, by both the number and resilience of general concepts extracted from them and readily extended to a larger group of species, ideally to all. For example, the chick and the importance of crest cells (Le Douarin, 2004), apoptosis in the nematode C. elegans (Hengartner and Horvitz, 1994), homeotic transformations (Lewis, 1978) or innate immunity (Lemaitre et al., 1996) in Drosophila and the existence of parental imprinting in mouse (Barton et al., 1984, McGrath and Solter, 1984), to name only a few, are trademarks of 'classical' models used in developmental biology over the past 40 years. It may take some more years for the serpent to emerge from under the flower and join the pantheon of model systems for developmental biology and genetics. Nothing does strictly prevent it to reach that stage, as long as enough scientists have time and interest to invest into this endeavor and that they can find the appropriate funding, which may be soon the most difficult obstacle to cross.

\section{Acknowledgements}

We thank Nicolas Di-Poï, Joost Woltering and Michel Milinkovitch for providing pictures as well as the University of Geneva, The Ecole Polytechnique Federale (EPFL) in Lausanne, the Swiss National Research Foundation, the ERC and the FP7 IDEAL program for funding.

\section{References}

ALFOLDI, J., DI PALMA, F., GRABHERR, M., WILLIAMS, C., KONG, L., MAUCELI, E., RUSSELL, P., LOWE, C.B., GLOR, R.E., JAFFE, J.D. et al., (2011). The genome of the green anole lizard and a comparative analysis with birds and mammals. Nature 477: 587-591.

ARNOULT, L., SU, K.F., MANOEL, D., MINERVINO, C., MAGRINA, J., GOMPEL, N. and PRUD'HOMME, B. (2013). Emergence and diversification of fly pigmentation through evolution of a gene regulatory module. Science 339: 1423-1426.

BARTON, S.C., SURANI, M.A. and NORRIS, M.L. (1984). Role of paternal and maternal genomes in mouse development. Nature 311: 374-376.

CARROLL, S.B. (2005). Evolution at two levels: on genes and form. PLoS Bio/3: e245.

CASTOE, T.A., BRAUN, E.L., BRONIKOWSKI, A.M., COX, C.L., RABOSKY, A.R., JASON DE KONING, A.P., DOBRY, J., FUJITA, M.K., GIORGIANNI, M.W., HARGREAVES, A. et al., (2012). Report from the first snake genomics and integrative biology meeting. Stand Genomic Sci 7: 150-152.

CASTOE, T.A., DE KONING, A.P., HALL, K.T., CARD, D.C., SCHIELD, D.R., FUJITA, M.K., RUGGIERO, R.P., DEGNER, J.F., DAZA, J.M., GU, W. et al., (2013). The Burmese python genome reveals the molecular basis for extreme adaptation in snakes. Proc Natl Acad Sci USA 110: 20645-20650.

CHENG, Y., MA, Z., KIM, B.H., WU, W., CAYTING, P., BOYLE, A.P., SUNDARAM, V., XING, X., DOGAN, N., LI, J. et al., (2014). Principles of regulatory information conservation between mouse and human. Nature 515: 371-375.

COHN, M.J. and TICKLE, C. (1999). Developmental basis of limblessness and axial patterning in snakes. Nature 399: 474-479.

COOPER, K.L., SEARS, K.E., UYGUR, A., MAIER, J., BACZKOWSKI, K.S., BROSNAHAN, M., ANTCZAK, D., SKIDMORE, J.A. and TABIN, C.J. (2014). Patterning and post-patterning modes of evolutionary digit loss in mammals. Nature 511: 41-45.

DE ROBERTIS, E.M. (2008). Evo-devo: variations on ancestral themes. Cell 132 185-195.

DI-POÏ, N., MONTOYA-BURGOS, J.I. and DUBOULE, D. (2009). Atypical relaxation of structural constraints in Hox gene clusters of the green anole lizard. Genome Res. 19: 602-610.

DI-POI, N., MONTOYA-BURGOS, J.I., MILLER, H., POURQUIE, O., MILINKOVITCH, M.C. and DUBOULE, D. (2010). Changes in Hox genes' structure and function during the evolution of the squamate body plan. Nature 464: 99-103.

DI-POÏ, N., MONTOYA-BURGOS, J.I., MILLER, H., POURQUIE, O., MILINKOVITCH, M.C. and DUBOULE, D. (2010). Changes in Hox genes' structure and function during the evolution of the squamate body plan. Nature 464: 99-103.

DUBOULE, D. (2005). Endless forms most beautiful - The new science of evo devo and the making of the animal kingdom. Science 308: 955-956.

DUBOULE, D. (2007). The rise and fall of Hox gene clusters. Development 134: 2549-2560.

DUBOULE, D. (2010). The evo-devo comet. EMBO reports 11: 489.

DUBOULE, D. and MORATA, G. (1994). Colinearity and functional hierarchy among genes of the homeotic complexes. Trends Genet. 10: 358-364.

FRY, B.G., VIDAL, N., NORMAN, J.A., VONK, F.J., SCHEIB, H., RAMJAN, S.F., KURUPPU, S., FUNG, K., HEDGES, S.B., RICHARDSON, M.K. et al., (2006). Early evolution of the venom system in lizards and snakes. Nature 439: 584-588.

GILBERT, C., MEIK, J.M., DASHEVSKY, D., CARD, D.C., CASTOE, T.A. and SCHAACK, S. (2014). Endogenous hepadnaviruses, bornaviruses and circoviruses in snakes. Proc Biol Sci 281: 20141122.

GOMEZ, C., OZBUDAK, E.M., WUNDERLICH, J., BAUMANN, D., LEWIS, J. and POURQUIE, O. (2008). Control of segment number in vertebrate embryos. Nature 454: 335-339.

GOMEZ, C. and POURQUIE, O. (2009). Developmental control of segment numbers in vertebrates. J Exp Zool B Mol Dev Evol 312: 533-544.

GREEN, R.E., BRAUN, E.L., ARMSTRONG, J., EARL, D., NGUYEN, N., HICKEY, G., VANDEWEGE, M.W., ST JOHN, J.A., CAPELLA-GUTIERREZ, S., CASTOE, T.A. et al., (2014). Three crocodilian genomes reveal ancestral patterns of evolution among archosaurs. Science 346: 1254449.

GUERREIRO, I., NUNES, A., WOLTERING, J.M., CASACA, A., NÓVOA, A., VINAGRE, T., HUNTER, M.E., DUBOULE, D. and MALLO, M. (2013). Role of a polymorphism in a Hox/Pax-responsive enhancer in the evolution of the vertebrate spine. Proc. Natl. Acad. Sci. USA 110: 10682-10686.

HARVEY, A.L. (2014). Toxins and drug discovery. Toxicon 92C: 193-200.

HEAD, J.J. and POLLY, P.D. (2015). Evolution of the snake body form reveals homoplasy in amniote Hox gene function. Nature 520: 86-89.

HELD I, L.J. (2014). How the Snake Lost its Legs: Curious Tales from the Frontier of Evo-Devo. Cambridge University Press.

HENGARTNER, M.O. and HORVITZ, H.R. (1994). C. elegans cell survival gene ced-9 encodes a functional homolog of the mammalian proto-oncogene bcl-2. Cell 76: 665-676.

KESSEL, M. and GRUSS, P. (1991). Homeotic transformations of murine vertebrae and concomitant alteration of Hox codes induced by retinoic acid. Cell 67: 89-104.

KMITA, M., FRAUDEAU, N., HERAULT, Y. and DUBOULE, D. (2002). Serial deletions and duplications suggest a mechanism for the collinearity of Hoxd genes in limbs. Nature 420: 145-150.

KOK, F.O., SHIN, M., NI, C., GUPTA, A., GROSSE, A.S., VANIMPEL, A., KIRCHMAIER, B.C., PETERSON-MADURO, J., KOURKOULIS, G., MALE, I. et al., (2014). Reverse Genetic Screening Reveals Poor Correlation between Morpholino-Induced and Mutant Phenotypes in Zebrafish. Dev Cell 32: 97-108.

LE DOUARIN, N.M. (2004). The avian embryo as a model to study the development of the neural crest: a long and still ongoing story. Mech Dev 121: 1089-1102.

LEMAITRE, B., NICOLAS, E., MICHAUT, L., REICHHART, J.M. and HOFFMANN, J.A. (1996). The dorsoventral regulatory gene cassette spatzle/Toll/cactus controls the potent antifungal response in Drosophila adults. Cell 86: 973-983.

LEWIS, E.B. (1978). A gene complex controlling segmentation in Drosophila. Nature 


\section{I. Guerreiro and D. Duboule}

276: 565-570.

LUTES, A.A., NEAVES, W.B., BAUMANN, D.P., WIEGRAEBE, W. and BAUMANN, P. (2010). Sister chromosome pairing maintains heterozygosity in parthenogenetic lizards. Nature 464: 283-286.

MCGRATH, J. and SOLTER, D. (1984). Completion of mouse embryogenesis requires both the maternal and paternal genomes. Cell 37: 179-183.

MCINTYRE, D.C., RAKSHIT, S., YALLOWITZ, A.R., LOKEN, L., JEANNOTTE, L., CAPECCHI, M.R. and WELLIK, D.M. (2007). Hox patterning of the vertebrate rib cage. Development 134: 2981-2989.

MENEZ, A., STOCKLIN, R. and MEBS, D. (2006). 'Venomics' or: The venomous systems genome project. Toxicon 47: 255-259.

MILINKOVITCH, M.C., MANUKYAN, L., DEBRY, A., DI-POI, N., MARTIN, S., SINGH, D., LAMBERT, D. and ZWICKER, M. (2013). Crocodile head scales are not developmental units but emerge from physical cracking. Science 339: 78-81.

MILINKOVITCH, M.C. and TZIKA, A. (2007). Escaping the mouse trap: the selection of new Evo-Devo model species. J Exp Zool B Mol Dev Evol 308: 337-346.

MURPHY, B.F. and THOMPSON, M.B. (2011). A review of the evolution of viviparity in squamate reptiles: the past, present and future role of molecular biology and genomics. J Comp Physiol B 181: 575-594.

NAGASHIMA, H., SUGAHARA, F., TAKECHI, M., ERICSSON, R., KAWASHIMAOHYA, Y., NARITA, Y. and KURATANI, S. (2009). Evolution of the turtle body plan by the folding and creation of new muscle connections. Science 325: 193-196.

POURQUIE, O. (2003). The segmentation clock: converting embryonic time into spatial pattern. Science 301: 328-330.

SATOH, N. and LEVINE, M. (2005). Surfing with the tunicates into the post-genome era. Genes Dev 19: 2407-2411.

SCHWARTZ, T.S., TAE, H., YANG, Y., MOCKAITIS, K., VAN HEMERT, J.L., PROULX, S.R., CHOI, J.H. and BRONIKOWSKI, A.M. (2010). A garter snake transcriptome: pyrosequencing, de novo assembly, and sex-specific differences. BMC genomics 11: 694.

SHAFFER, H.B., MINX, P., WARREN, D.E., SHEDLOCK, A.M., THOMSON, R.C., VALENZUELA, N., ABRAMYAN, J., AMEMIYA, C.T., BADENHORST, D., BIGGAR, K.K. et al., (2013). The western painted turtle genome, a model for the evolution of extreme physiological adaptations in a slowly evolving lineage. Genome Biol 14: R28.

SHINE, R. and BONNET, X. (2000). Snakes: a new 'model organism' in ecological research? Trends Ecol Evol 15: 221-222.

SIMONS, C., PHEASANT, M., MAKUNIN, I.V. and MATTICK, J.S. (2006). Transposonfree regions in mammalian genomes. Genome Res. 16: 164-172.

SMITH, K. and SPADAFORA, C. (2005). Sperm-mediated gene transfer: applications and implications. BioEssays 27: 551-562.
SOMMER, R.J. (2009). The future of evo-devo: model systems and evolutionary theory. Nat Rev Genet 10: 416-422.

STERGACHIS, A.B., NEPH, S., SANDSTROM, R., HAUGEN, E., REYNOLDS, A.P., ZHANG, M., BYRON, R., CANFIELD, T., STELHING-SUN, S., LEE, K. et al., (2014). Conservation of trans-acting circuitry during mammalian regulatory evolution. Nature 515: 365-70.

TABIN, C. and WOLPERT, L. (2007). Rethinking the proximodistal axis of the vertebrate limb in the molecular era. Genes Dev. 21: 1433-1442.

TZIKA, A. and MILINKOVITCH, M.C. (2008). A Pragmatic Approach for Selecting Evo-Devo Model Species in Amniotes. In Evolving Pathways; Key Themes in Evolutionary Developmental Biology, (ed. MINELLI, A. and FUSCO, G.). Cambridge University Press, Cambridge, pp.119-140.

TZIKA, A.C., HELAERS, R., SCHRAMM, G. and MILINKOVITCH, M.C. (2011) Reptilian-transcriptome v1.0, a glimpse in the brain transcriptome of five divergent Sauropsida lineages and the phylogenetic position of turtles. EvoDevo 2: 19.

VIDAL, N. and HEDGES, S.B. (2004). Molecular evidence for a terrestrial origin of snakes. Proc. Royal Soc. London B: Biol. Sci. 271: S226-S229.

VONK, F.J., CASEWELL, N.R., HENKEL, C.V., HEIMBERG, A.M., JANSEN, H.J., MCCLEARY, R.J.R., KERKKAMP, H.M.E., VOS, R.A., GUERREIRO, I., CALVETE, J.J. et al., (2013). The king cobra genome reveals dynamic gene evolution and adaptation in the snake venom system. Proc. Natl. Acad. Sci. USA 110:20651-20656.

WANG, Z., PASCUAL-ANAYA, J., ZADISSA, A., LI, W., NIIMURA, Y., HUANG, Z., LI, C., WHITE, S., XIONG, Z., FANG, D. et al., (2013). The draft genomes of softshell turtle and green sea turtle yield insights into the development and evolution of the turtle-specific body plan. Nat Genet 45: 701-706

WELLIK, D.M. (2003). Hox10 and Hox11 Genes Are Required to Globally Pattern the Mammalian Skeleton. Science 301: 363-367.

WOLTERING, J.M. (2012). From lizard to snake; behind the evolution of an extreme body plan. Curr. Genomics 13: 289-299.

WOLTERING, J.M., VONK, F.J., MÜLLER, H., BARDINE, N., TUDUCE, I.L., DE BAKKER, M.A.G., KNÖCHEL, W., SIRBU, I.O., DURSTON, A.J. and RICHARDSON M.K. (2009). Axial patterning in snakes and caecilians: Evidence for an alternative interpretation of the Hox code. Dev. Biol. 332: 82-89.

YOUNG, T. and DESCHAMPS, J. (2009). Hox, Cdx, and anteroposterior patterning in the mouse embryo. Curr Top Dev Biol 88: 235-255.

YOUNG, T., ROWLAND, J.E., VAN DE VEN, C., BIALECKA, M., NOVOA, A. CARAPUCO, M., VAN NES, J., DE GRAAFF, W., DULUC, I., FREUND, J.-N. et al., (2009). Cdx and Hox genes differentially regulate posterior axial growth in mammalian embryos. Developmental Cell 17: 516-526.

YUE, F.CHENG, Y.BRESCHI, A.VIERSTRA, J.WU, W.RYBA, T.SANDSTROM, R.MA Z.DAVIS, C.POPE, B.D. et al., (2014). A comparative encyclopedia of DNA elements in the mouse genome. Nature 515: 355-364. 


\section{Further Related Reading, published previously in the Int. J. Dev. Biol.}

Sexual dimorphism of AMH, DMRT1 and RSPO1 localization in the developing gonads of six anuran species

Rafal P. Piprek, Anna Pecio, Katarzyna Laskowska-Kaszub,Jacek Z. Kubiak and Jacek M. Szymura

Int. J. Dev. Biol. (2013) 57: 891-895

Dual embryonic origin of the hyobranchial apparatus in the Mexican axolotl (Ambystoma mexicanum)

Asya Davidian and Yegor Malashichev

Int. J. Dev. Biol. (2013) 57: 821-828

Clonal analyses in the anterior pre-placodal region: implications for the early lineage bias of placodal progenitors

Sujata Bhattacharyya and Marianne E. Bronner

Int. J. Dev. Biol. (2013) 57: 753-757

Amphibian interorder nuclear transfer embryos reveal conserved embryonic gene transcription, but deficient DNA replication or chromosome segregation Patrick Narbonne and John B. Gurdon

Int. J. Dev. Biol. (2012) 56: 975-986

Origins of $C d x 1$ regulatory elements suggest roles in vertebrate evolution Stephen J. Gaunt and Yu-Lee Paul

Int. J. Dev. Biol. (2011) 55: 93-98

Reptile scale paradigm: Evo-Devo, pattern formation and regeneration

Cheng Chang, Ping Wu, Ruth E. Baker, Philip K. Maini, Lorenzo Alibardi and Cheng-Ming Chuong

Int. J. Dev. Biol. (2009) 53: 813-826

Proteomics analysis of regenerating amphibian limbs: changes during the onset of regeneration

Michael W. King, Anton W. Neff and Anthony L. Mescher

Int. J. Dev. Biol. (2009) 53: 955-969

5 yr ISI Impact Factor $(2013)=2.879$
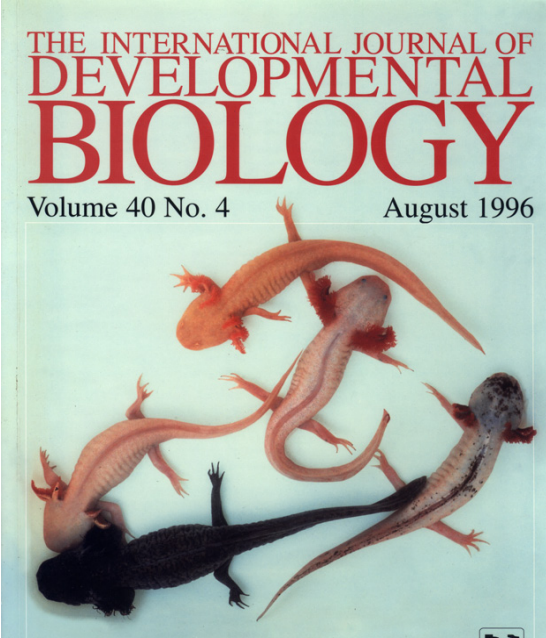

Developmental Biology of Urodeles

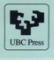

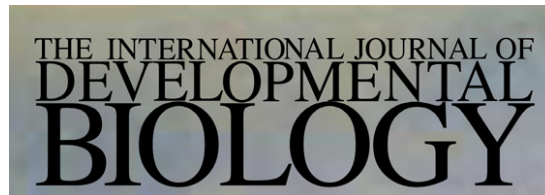

Volume 47 Nos. $7 / 8$

Special Issue

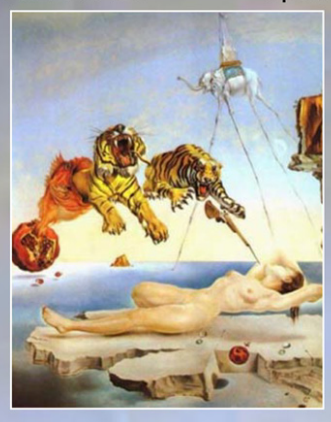

Evolution \& Development
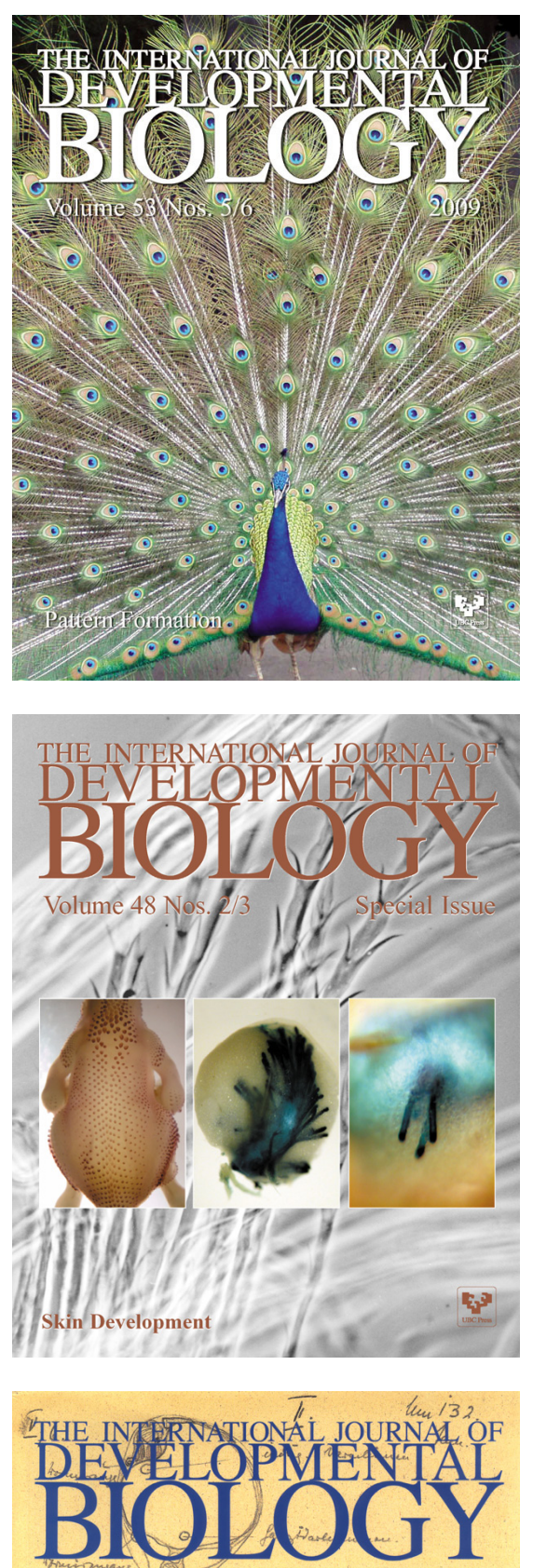

Volume 45 No. 1

Special issue

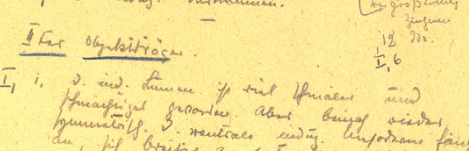

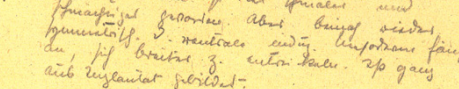

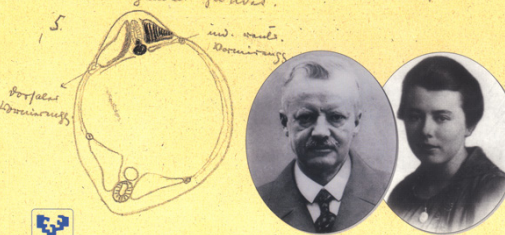

\&

The Spemann-Mangold Organizer 